\title{
Border Residents and Cross border Crimes in Ghana: An Empirical Study of Aflao
}

\author{
Dr. Ishmael K. Hlovor \\ P.O Box LG 130, Legon Ghana
}

\begin{abstract}
Border residents have been noted for their involvement in goods smuggling and other illegal cross border exchanges as coping mechanisms for poverty and unemployment. This study assesses the veracity of this claim through a field survey of the eastern border town of Aflao. The result of the study shows that challenges of poverty and unemployment have forced border residents to exploit their location in the border space as coping strategy by engaging in officially proscribed activities. These activities involve crimes such as goods smuggling, smuggling facilitation, armed robbery and petty stealing, drug trafficking, human trafficking and arms trafficking. While border residents are likely to see some of these activities (armed robbery and petty stealing, drug trafficking, human trafficking and arms trafficking) as crimes, they would normally accept that goods smuggling and aiding smuggling are not crimes because they serve as livelihood options, which contribute to reducing unemployment and poverty in border areas. To be effective, border management has to be comprehensive and incorporate the livelihood needs of Borderlanders.
\end{abstract}

Keywords: Cross border crimes, Borderlanders, Frontier, Smuggling, Unemployment

\section{Introduction}

In Africa, porous borders, marginalization of border populations and excessive centralization of state po wer, state weakness and the inability of the state to effectively control the full stretch of national borders have created what is termed "ungoverned space" or the "alternatively governed" areas mainly around border areas (Ismail, 2013; Agade, 2014; Clunan \& Trinkunas, 2010). These spaces have been strategically exploited by transnational criminal groups including terrorist groups, arm traffickers, and human traffickers to carry out their nefarious activities (Ismail, 2013). For example, in West Africa, terrorist groups such as Bokom Haram, AQIM and Ansar Dine have exploited weak border security systems and border porosity to undermine both national and regional security in border regions. Boko Haram, for instance, operates from bases in the remote border areas between Nigeria, Chad, and Cameroon. AQIM has found fertile grounds in the border regions of the Sahel including the border regions of Northern Mali, Southern Algeria and Northern Niger.

Notwithstanding the relative stability of Ghana, the country faces many transnational security issues that are connected or facilitated by porous and poorly managed borders (Sosuh, 2011). Issues of drug trafficking, human trafficking, arms trafficking, and smuggling of goods across the borders pose security threats of different proportions to the country. There is evidence that the country has become a major hub for drug traffickers trying to reach Europe and North America (Cockayne, 2011). The country is also said to be an origin, transit point and destination for men, women and children trafficked both within the country and outside it (US Department of State, 2016). In addition, the smuggling of commodities like cloths, drinks and other daily consumables into the country are undermining the country's manufacturing sectors as well as the ability of government to generate revenue from taxes. There is also loss of revenue to the state as a result of smuggling of cocoa, agriculture inputs (particularly government subsidize fertilizers), and petroleum products out to the three neighbouring countries of Cote deIvoire, Burkina Faso, and Togo (Kumar, 1973; Nugent, 1991; Oxford Business Group, 2013; Buliř, 1998).

Many of these transnational crimes have been aided by border residents who have intimate knowledge of the border terrain. For instance, Azure Junior (1999) documented how border resident aid the smuggling 
of goods, particularly pirated textile across the eastern border into Ghana. In drug trafficking, there is evidence that local fishermen aid the smuggling of drugs into Ghana. Large shipments at sea are often broken into smaller packages and offloaded onto small fishing vessels, which carry the drug on shore unnoticed. In Ghana, the narcotics are repackaged and hidden in shipping containers or air cargo, and trafficked out of the country (US State Department, 2014).

The Immigration Service Act (2000) is defines border-resident as "a national of a neighbouring country who ordinarily resides within five kilometres radius of either side of Ghana's territory frontiers with Republics of Togo, Burkina Faso and Cote d'Ivoire." Although, the definition does not apply to Ghanaians, this study extends it to them by defining border residents as persons who reside within five kilometres radius of either side of Ghana's territory frontiers both Ghanaians and people of other nationalities. However, the focus is on the activities of border residents in Ghana. The study also uses border residents and borderlanders interchangeably.

Studies on the activities of border residents in Ghana have pointed to their involvement in goods smuggling and other illegal cross border exchange as coping mechanisms to poverty and unemployment (Nugent, 2011; Nugent, 2002; Raunet, 2016; Chalfin, 2001; Nugent, 1991). Thus, smuggling and other illegal cross border activities are important parts of the border economy. This study assesses the veracity of this claim through a field survey of the eastern border town of Aflao. Two major issues are assessed by the study. First, what are the main problems facing border residents? Secondly, does the involvement of border residents in cross border crimes provide the means to address poverty and limited employment opportunity in borderlands as ethnographic studies have shown?

\section{Theoretical Framework: Classic Strain Theory}

One of the commonly employed theories of crime is the classic strain theory advanced by Merton (1983), Cohen (1955) and Cloward and Ohlin (1960). According to Merton (1983), societies or social groups normally have culturally defined goals, purposes and interests. According to him, "every social group invariably couples its scale of desired ends with moral or institutional regulations of permissible and required procedure for attaining these ends" (Merton, 1983, p. 673). Crime is restricted if the society provides sufficient legitimate avenues through which members can reach the agreed goals. On the other hand, when a society does not provide sufficient legitimate avenues through which people can attain shared goals, crime may be common. Merton expounded the theory as an explanation for crime among low-income Americans. The theory assumes that lack of legitimate opportunities (lack of education, low qualities schools, failure to secure well-paying jobs, and failure of parents to set them up in business) prevents low income children from living the American shared goal of monetary success. Crimes (theft, robbery, etc.), provides one of the means of coping with the strains experience by low-income Americans.

The classic strain theory was further developed by Albert Cohen (1955) to explain the origins of gangs or gang culture among low class adolescents in the 1950s. He posited that low class people aimed to achieve middle class status (both in terms of monetary status and respect) but were unable to achieve that legitimately due to limited opportunities (low quality schools and lack of education). However, since class status cannot be attained through illegitimate means, some of the lower class adolescents cope with the strain by developing an alternative social status system or deviant subcultures. This alternative status system takes the form of gangs and involves rejection of the socially accepted values of the middle class. Thus, instead of respect for private property and polite behaviour, which are valued among the middle class, violence, aggression and theft are the cherished values of gangs.

Cloward and Ohlin (1960) built on the theory by explaining that the formation of gangs is the result of the failure of lower class people to achieve shared social goals through legitimate means. Their main contribution to the theory is that engagement in crimes is not only due to the failure to achieve goals by conventional means but also availability of the skills and the opportunities to engage in crime.

For classic strain theorists, economic success is the main goal of society. Thus, the heart of the theory is that poor people often experience strain because there is little or limited conventional means to achieve their goals of economic success. The validity of the theory was, however, questioned in the 1960s due to the lack of empirical evidence to support the relationship between crime and class. In particular, the theory failed to account for crime among middle class and upper class people (Jang \& Agnew, 2015; Agnew, 2000). However, recent advocates of the classic strain theory have argued that people assess their economic circumstance or achievements not only in absolute terms but also in relative terms (Baron, 2014; Burton \& 
Dunaway, 1994; Parker, 2008). Thus, middle class or high class people may engage in crimes due to a sense of being worse off in comparison with others in their social group. In other words, people with higher aspirations but lower actual achievement of goals, may experience strain regardless of class and engage in crime as a means to cope (Agnew, 2016). In extremely poor groups, the need to meet the basic necessities of life (food, shelter and clothing) can compel them into crime, whereas in other groups, relative deprivation may drive them into crime. Although various coping mechanisms ensure that not all people who are unable to achieve goals resort to crime, poorer people are more likely to engage in crime because they are more likely to experience goal blockage and relative deprivation (Agnew, 2016, p. 212).

Two issues are important in discussing the engagement of African border residents in cross border crimes. One is relative poverty of border areas due to the ambivalent presence of the state in border areas. The state is present in the extraction of revenue but almost non-existing in the provision of economic and other social infrastructure. Africa border areas are among the most neglected parts of Africa with many ungoverned areas. In areas, where the state is present, little effort is made to incorporate the needs of borderlanders into border control efforts. Limited legitimate job opportunities and poverty in border areas have allowed for the emergence of a subculture in border areas where the illegitimate is legitimized. Cross border criminal activities have become effective means of achieving economic goals. Since the economic goals (in most cases for African borderlanders is an issue of meeting the basic necessities of life) need to be met for survival or wellbeing of border residents, the question is not about the means to achieving the goal but the most effective and available means to achieve it (Merton, 1983, p. 674).

That leads to the second issue which involves the availability of opportunities to engage in cross border crimes. To start with, borderlands are unique subcultures (Konrad, 2014). African borders provide both opportunities, conduits and barriers to cross border exchanges (Nugent \& Asiawuja, 1996). Some of these exchanges are illicit but effective in achieving monetary and livelihood gains. In most border areas, border residents have seized the opportunity provided by the presence of borders to engage in cross border exchange of all kinds. The so called border economy provides for legal and illegal opportunities for residents. The limited nature of legal or legitimate avenues has led many border residents to turn to the illegal or illegitimate but effective and available means to achieve economic goals. Indeed, borderlanders also have the skills and expertise to engage in the cross border crimes. They have deep-rooted knowledge of the border terrain and the ability to draw border agencies into compromise by appealing to history and norms that govern everyday life in the border space. (Flynn, 1997; Galemba, 2012; MacGaffey, 1991; Nugent, 2011). Besides, returns on legitimate work may not be as attractive as those offered by crimes like goods smuggling. Thus, border residents' engagement in cross border crimes is both a matter of goal blockage and availability of the opportunity and the skills to engage in crime. By legitimizing illegal cross border activities, it provides one of the coping mechanisms for poor border communities and residents to cope with their economic challenges.

\section{Review of the Literature}

Globalization and revolution in the means of transport have led to significant improvement in the ability of goods and people to travel the world more easily and rapidly. Modern border governance systems have the dual mandate of guaranteeing territorial access to legitimate actors while preventing harmful actors from doing same. This task demands the prevention of an ever growing number of transnational or cross border criminals from engaging in activities considered to be harmful to the state and the economy.

Frontier areas or borderlands are zones of integration and transition of various social, economic and political processes (Kristof, 1959). All borderlands are influenced by the presence of the border and all borderlanders have the "border experience" (Martínez, 1994, p. xviii). These areas, which are mainly at the periphery of the state are governed by economic, social, and political processes distinct from similar processes in other parts of the state (Martínez, 1994; Konrad, 2014; Kristof, 1959). Borderlands have physical and culture features produced by the interplay of cultures and borders, thereby, producing unique subcultures (Konrad, 2014, p. 41). Konrad noted that the subculture of borderlands "both engages and resists the dominant cultures on either side of the border" (Konrad, 2014, p. 43). One aspect of this subculture is the engagement in activities officially proscribed yet effective in meeting the economic or survival goals of border residents (McGregor, 2008; Flynn, 1997; MacGaffey, 1991; Collins, 1985; Galemba, 2012). As aptly stated by Abraham and van Schendel (2005, p. 29) border areas are social spaces where illegal cross-border flows become "naturalized and intersected" with legal flows. 
In West Africa, the growth of transnational criminal networks and cross border crimes has posed challenges to state stability, governance and security within the sub-region (Adeyemi, 2015; Aning, 2007; Addo, 2006; Mazzitelli, 2007 ). This situation demands effective and efficient border security systems. This is because an effective regulation of cross border activities in a manner that prevents and sanctions cross border criminal activities would enhance peace, stability and facilitate the socio-economic integration of the sub region (Addo, 2006). Yet, it should be noted that the effective regulations of cross border activities in order to prevent cross border crimes is also dependent on improvement in state capacity, justice administration, political stability and the level of integration of the relevant stakeholders across borders in the region (Mazzitelli, 2007 ; Addo, 2006).

The prevalence of cross border crimes across the region has been attributed to porous and poorly demarcated borders, official corruption, inadequate state capacity, ineffective judicial systems and poverty among others (Addo, 2006; Mazzitelli, 2007 ; Adeyemi, 2015; Aning, 2007). The role of border residents in the perpetration of these crimes have not really engaged scholarly attention, although few studies into the border economies have highlighted the activities of border residents in influencing border management, especially engagement in cross border trading (both illicit and licit) (Collins, 1985; Flynn, 1997; Nugent, 2011; MacGaffey, 1991).

Ghana faces many transnational crimes including goods smuggling, human trafficking, drug trafficking, piracy, and money laundering. These issues have been widely investigated within the confines of the border or transnational security situation in Ghana (Sosuh, 2011; Azure Junior, 1999; Kumar, 1973; Quaye \& Coombs, 2011; Aning, 2007; Akyeampong, 2005; Addo, 2006). Among the many variables, transnational crimes in Ghana are attributed to the inability of the country to govern its borders effectively (Sosuh, 2011; Aning, 2007; Azure Junior, 1999). Institutional challenges including the lack of modern border infrastructure and facilities, inadequate capacity of border security agencies and other relevant supporting actors within the border security arena are among the many variables often cited for ensuring transnational crimes (Sosuh, 2011; Azure Junior, 1999).

Available literature on the involvement and the role of border residents in cross border crimes is limited. The main focus of research on border residents is their role in the border economy, which is an informal economy of cross border trading. Literature on the border economy has focused on the relation between border residents and border agents in everyday activity of regulating cross border mobility. It has been identified that border residents have acquired deep-rooted economic interest in the border and employed informal rules derived from every day practice and the history of cross border mobility to circumvent state rules, thereby engaging in what officially constitute crimes (Nugent, 2002; Lentz, 2003; Nugent, 2011; Chalfin, 2001) .

Chalfin (2001) explored the implications of cross border trade for state power at the margins of the Ghanaian state by focusing on the north-east border zone of Ghana, Burkina Faso and Togo. This area he noted is a zone of extreme mobility of people and goods, as well as a high degree of state surveillance. He pointed out that the routines of cross border traders have led to the activation of state regulation thereby bringing the physical territorial and administrative expression of the state into being. As cross border traders contravene state regulations, they invite the sanction and collusion of the state and in the process, they establish "a modus operandi for state agents stationed at the border" (Emphas is in the original) (Chalfin, 2001, p. 203). He observed that, in northern Ghana, illicit trade contributes to both the "discursive constitution of state power" and "its practical and experiential realisation" (Chalfin, 2001, p. 220). He concluded that options for social and political interactions and practices in border zones are conditioned by material circumstances or the need for economic survival. Activities of borderlanders are motivated by the desire to meet economic and survival goals, hence, contravening state regulation within this space is undertaken as a means to obtain livelihood.

Nugent $(2002,2011)$ provides an in-depth understanding of the local interest at border areas, using the eastern frontier of Ghana. Focusing on smuggling, he noted that, the border has created strong local interests bent on maintaining it instead of attempts at redrawing it due to its economic benefits. The residents along the Ghana-Togo border have actively engaged with the border and have sought to shape it to their local interest, mainly their economic interest. Smuggling he noted is widespread and regarded as 'a legitimate business' among the locals. He equally noted that everyday practice of border agencies along the border has been influenced by informal codes of practice created through interaction with the border communities. Such informal rules emerged from the history of cross border movement and exchange, which has created 
codes of conducts that border residents appeal to in cases of conflict with border agencies and state law. Border agents learn these rules on arrival at post and informally accept them (Nugent, 2011).

By relaying on informal rules or codes, borderlanders are able to continue engagement in cross border activities that are legally crimes. Thus, the state and society at the margins are in constant interaction and negotiation of state practices. Bureaucratic practices are conditioned by the social environment and, in the border space, this reality may be more determinate of everyday border management practices than formal rules. The limited knowledge of border security agents about illegal cross border routes and the general terrain plays to the advantage of local smugglers, who are said to have intimate knowledge of the border terrain (Lamptey, 2013).

Similar observation has been made by Raunet (2016) in his study of the role of chiefs in controlling cross border mobility. He noted that the state is not the only legitimate actor in control of cross border mobility in the borderland. Using the Ghana-Togo borderlands, he demonstrated how traditional chiefs within the border space have historically used their presence to participate in influencing the regulation of cross border mobility under colonial rule and after independence. He noted that borderland chiefs are "gatekeepers at the crossroads between state borders, borderland villages' limits, and regional organizations (ECOWAS promoting free movement and WAEMU)" (Raunet, 2016, p. 5). Being in a position of power due to their distance from the capital, the seat of power, and location in the borderlands, chiefs within borderlands "...are both a competing authority to the state in terms of cross-border livelihoods and smuggling, but also indispensable allies acting as mobility gatekeepers" (Raunet, 2016). Cross border mobility and official practices to regulate them are constantly negotiated and influenced by borderland chiefs according to their interests. Their influence is necessary to guarantee their subjects cross border mobility and livelihood derived mainly from cross border exchanges.

Carola lentz also investigates how Ghana's northern border with Burkina Faso has been appropriated by border residents as a political resource. In the colonial era, he noted that the border was employed by residents to evade forced labour and taxation in Burkina Faso. (Lentz, 2003) He also noted that some residents tacitly shifted allegiance to the British although from the very beginning all borderlanders knew the colonial power their farmland or village belong. The borderlanders he observed give different meanings and interpretation to the border depending on their interest. In local land use and kinship, they usually ignore the border but strategically appeal to it during periods of conflict over land and resource use.

However, as Agbedahin (2014) observed along the Ghana-Togo border, border agencies are partly responsible for border porosity as they shift their jurisdiction to a multi-layered border parasitism. He demonstrated that border agencies have contributed to border porosity as they become dependent on smugglers for extra income. They are in collusion with smugglers to facilitate illegal exchange across the border.

Aning (2007) in his study of the rise of transnational criminal networks in Ghana also shows that cultural ethos and social welfare role of criminals have provided legitimacy to these criminals among the local population. He also noted that unemployment and poverty has provided a large body of men and women who can be recruited by these criminal groups. He observed a legal dualism in terms of the relationship between modern law, which represents official government position and traditional system operating through the sanctions of moral codes. The operations of the modern law, which characterized many activities as crimes is influenced by the traditional systems. Thus, while an activity may be illegal in modern law, culture and traditional norms uphold them. Activities rooted in the culture and tradition, yet considered as crimes in modern law has led to disregard for modern laws (Aning, 2007, p. 210). Although, Aning focused mainly on the general Ghanaian society, the observation of the role of culture ethos is important as the subculture of borderlands may play an important role in influencing involvement of borderlanders in cross border crimes. Acceptance of practices such as smuggling may be legitimized by long periods of exchanges among the groups prior to the imposition of the border.

Border residents in Ghana are important actors within the border space and influence the management of borders. Like borderlanders elsewhere, they engage in cross border activities, which are proscribed by the state to overcome limited livelihood opportunities. They influence the daily practice of border management by appealing to unwritten codes of conduct, which have been institutionalized through years of practice. Although, available literature has documented the activities of border residents in influencing border management and in engaging in officially proscribed activities, scholars have tend to see these activities as an aspect of the everyday life of borderlanders. Yet, many of these activities are crimes, regardless of the 
subculture that legitimize them. This paper proceeds by acknowledging that although the subculture within borderlands have legitimized illicit cross border activities of border people, these activities remain crimes in modern Ghanaian law. In addition, the activities of borderlanders have been analyzed mainly through ethnographic studies of the borderland economy and culture. There is currently no survey evidence on the issue. This paper is an attempt to fill this lacuna in the literature by employing field survey in order to provide evidence in support of the current view or otherwise.

\section{Methodology}

This study is a field survey of the opinion of residents of Aflao on the nature of cross border crimes involving residents. It is part of a larger study into the activities of border communities in border security in Ghana. The population of interest to the study is the entire adult population of Aflao, that is all residents who are 18 years and above. The study employs the quota sampling technique. This is a non-probability sampling technique, which involves the selection of a sample from a group by first dividing the group into subgroups referred to as strata. Depending on the qualities of each group in relation to the total population as well as the goal of the research, the researcher then draw from each strata a particular number of respondents to form the sample. (Foreman, 1991; Bailey, 1994) This method was used to sample 500 people from the Aflao Township for the administration of questionnaires. To achieve this, the Township was first divided into four zones, representing north, south, east and west. Based on these imagery divisions or strata, 125 houses were selected from each division. This was done by selecting the first house of each division randomly and fifth house thereafter until 125 houses were selected. One person from each house, the one willing to volunteer information or the person chosen by the members of the house was selected for the questionnaire administration. The data for the study was collected between September 2016 and February 2017.

\section{Findings}

The number of female respondents was 50.2 percent and male respondents constituted 49.8 percent. Majority of the respondents were within the age bracket of 18-25 years and 26-35 years. The number of respondents within each of these two age groups was 35.8 percent. This translates to some 71.6 percent of the respondents being between the ages of 18 and 35 years. There were also 14.6 percent of the respondents within the age group of 36-45 years. The remaining 13.8 percent of the respondents were within the age group of 46-55 years. Among the respondents, 10.8 percent of the respondents had no form of formal education, 42.2 percent had only basic education (primary education or Junior High School education), 37 percent of the respondents had Senior High School education and 10 percent had tertiary education. (Refer to Table 1)

Table 1 Gender, Age and Educational

\begin{tabular}{|c|c|c|}
\hline & & Percent \\
\hline \multirow[t]{2}{*}{ Gender } & Male & 49.8 \\
\hline & Female & 50.2 \\
\hline \multirow[t]{4}{*}{ Age } & $18-25$ & 35.8 \\
\hline & $26-35$ & 35.8 \\
\hline & $36-45$ & 14.6 \\
\hline & $46-55$ & 13.8 \\
\hline \multirow[t]{4}{*}{ Education } & No Education & 10.8 \\
\hline & Primary/JHS & 42.2 \\
\hline & Senior High School & 37.0 \\
\hline & Tertiary & 10.0 \\
\hline
\end{tabular}

Source: Fieldwork, 2016

In terms of employment status, 8 percent of the respondents were farmers, majority 39.4 percent were traders or businesspersons. (Refer to table 2)

Table 2: Occupation of the Respondents

\begin{tabular}{|l|l|l|}
\hline & Frequency & Percentage \\
\hline Farmer/fishermen & 40 & 8.0 \\
\hline Trader/Businesspersons & 197 & 39.4 \\
\hline
\end{tabular}




\begin{tabular}{|l|l|l|}
\hline Student & 90 & 18.0 \\
\hline Formal Sector/Government Employee & 70 & 14.0 \\
\hline Unemployed & 63 & 12.6 \\
\hline Artisan & 40 & 8.0 \\
\hline Total & 500 & 100.0 \\
\hline
\end{tabular}

Source: Fieldwork, 2017

The data also showed that some 18.0 percent of the respondents were students, while 14.0 percent were government/formal sector employees. Some 12.6 percent of the respondents were unemployed and 8 percent of them were artisans. However, it is important to note that the government/formal sector employs fewer numbers of the respondents than the informal sectors. The informal sector (farming, business or trading, artisan) collectively employs over 55 percent of the respondents. If this figure were expressed in terms of only those who were employed, it would lead to the informal sector employing an estimated 84 percent of the respondents who were employed. This shows that the border economy is essentially an informal economy with many of the residents engaged in trading and business.

Respondents of the study largely fall within a low-income category. Among the respondents, 51.8 percent of them stated that their monthly income was less than GHC500 and 30.4 percent also noted that their monthly income was between GHC 500-1,000. The students and unemployed people sampled for the study influenced the large number of respondents earning less than GHC500. (Refer to table 3)

Table 3 Monthly income of Respondents

\begin{tabular}{|l|l|l|}
\hline & Frequency & Percent \\
\hline Less down 500GHC & 259 & 51.8 \\
\hline $500-1000 \mathrm{GHC}$ & 152 & 30.4 \\
\hline $1100-2000 \mathrm{GHC}$ & 70 & 14.0 \\
\hline $2100-3000 \mathrm{GHC}$ & 9 & 1.8 \\
\hline Above 3000 GHC & 10 & 2.0 \\
\hline Total & 500 & 100.0 \\
\hline
\end{tabular}

Source: Fieldwork, 2016

Almost half of those earning less than GHC500 were from these two groups. For instance, out of the 63 respondents who were unemployed only 9 agreed to be earning a monthly income of more than GHC 500 . The same applies to the 90 students sampled by the study, only 7 stated that their monthly income was above GHC 500 (see table 4 for details).

Table 4: Occupation Cross tabulation (Level of Income and Occupation)

\begin{tabular}{|c|c|c|c|c|c|c|c|}
\hline & \multicolumn{5}{|c|}{ What is the estimated value of your monthly income } & \multirow[t]{2}{*}{ Tota } \\
\hline & & $\begin{array}{c}\text { Less down } \\
\text { GHC } 500\end{array}$ & $\begin{array}{c}\text { Between } \\
500-1000\end{array}$ & $\begin{array}{c}1100- \\
2000\end{array}$ & $\begin{array}{c}2100- \\
3000\end{array}$ & $\begin{array}{c}\text { Above } \\
3000\end{array}$ & \\
\hline \multirow{6}{*}{$\begin{array}{l}\text { Occup } \\
\text { ation }\end{array}$} & Farmer/fisherman & 23 & 10 & 7 & 0 & 0 & 40 \\
\hline & Trader/businessperson & 82 & 88 & 14 & 4 & 9 & 197 \\
\hline & Student & 83 & 7 & 0 & 0 & 0 & 90 \\
\hline & Government Employee & 2 & 19 & 44 & 4 & 1 & 70 \\
\hline & Unemployed & 54 & 9 & 0 & 0 & 0 & 63 \\
\hline & Artisan & 15 & 19 & 5 & 1 & 0 & 40 \\
\hline \multicolumn{2}{|r|}{ Total } & 259 & 152 & 70 & 9 & 10 & 500 \\
\hline
\end{tabular}

Source: Fieldw ork, 2016

For these two groups income does not necessarily mean money in return for work done since they are dependent on others. Hence the study allowed the respondents within these two groups to give estimates of what they receive from their sponsors mostly their friends and relatives as well as occasional jobs they do within a month. Even among traders or businesspersons, 41.6 percent of them stated that they earn less than GHC 500 and over half of farmers fell within this income group. Some 14 percent and 1.8 percent of the

${ }^{1}$ GHANA CEDI (GHC) IS NATIONAL CURRENCY OF THE REPUBLIC OF GHANA. THE EXCHANGE RATE TO THE US DOLLAR AS AT $31^{\text {ST }}$ DECEMBER 2016 WAS GHC 4.28 TO \$1.00XE.COM, “CURRENCY TABLES" AT HTTP:/WWW.XE.COM/CURRENCYTABLES/?FROM=USD\&DATE=2017-01-02 (ACCESSED 3 JANUARY, 2017) 
respondents fell within the monthly income group of GHC 1,100 -2,000 and GHC 2,100-3,000 respectively. In addition, 2 percent of the respondents earned a monthly income above GHC3,000.

The income leveldecreases as the population of respondents' increases implying that very few of them were on higher incomes. Monthly incomes are better among government and formal sector employees in the area as majority in that group earn income above $\mathrm{GHC}$ 500. It is however important to point out that many of the informal sector workers find it difficult to keep record of their monthly earnings. Many of them struggled to come up with the income level during the administration of the questionnaires. In addition, notwithstanding assurances of confidentiality, many of the respondents were still suspicious and in spite of evidence of higher income, intentionally underestimated their earnings.

The respondents were asked to state the main challenges facing their community. Among the challenges, unemployment and poverty was stated as the main challenge, with 96 percent of the responses. The issue of limited social amenities was the second most mentioned challenge with 90 percent of the responses. Armed robbery and petty stealing, and drug abuse were the third and the fourth most mentioned problem with 80 and 74 percent respectively. The other challenges include human smuggling (66\%), lack of respect for cultural norms and values (64\%), prostitution and other social vices (60\%), HIV/AIDS and other sexually transmitted diseases (60\%), lack of educational opportunities (54\%), drug smuggling (54\%), lack of security protection (46\%), arms smuggling (46\%), and housing and accommodation (44\%). (Refer to table 5)

Table 5: What are the main challenges facing your community?

\begin{tabular}{|l|c|c|c|}
\hline \multirow{2}{*}{} & $\mathrm{N}$ & \multirow{2}{*}{ Percent of Cases } \\
\cline { 2 - 3 } & & $\mathrm{t}$ & \multirow{2}{*}{ Percen } \\
\hline Unemployment and Poverty & 480 & $11.5 \%$ & $96.0 \%$ \\
\hline Lack of Educ ational Opportunities for Youths & 270 & $6.5 \%$ & $54.0 \%$ \\
\hline High Rate of STDs including HIV/AIDS & 300 & $7.2 \%$ & $60.0 \%$ \\
\hline Lack of Security Protection & 230 & $5.5 \%$ & $46.0 \%$ \\
\hline Prostitution and other social vices & 300 & $7.2 \%$ & $60.0 \%$ \\
\hline Housing and Accommodation Problem & 220 & $5.3 \%$ & $44.0 \%$ \\
\hline Drug abuse among the youth & 370 & $8.9 \%$ & $74.0 \%$ \\
\hline Armed robbery and Petty Stealing & 400 & $9.6 \%$ & $80.0 \%$ \\
\hline lack of respect for culture norms and values & 320 & $7.7 \%$ & $64.0 \%$ \\
\hline Limited social amenities & 450 & $10.8 \%$ & $90.0 \%$ \\
\hline Drug Smuggling & 270 & $6.5 \%$ & $54.0 \%$ \\
\hline Human Smuggling & 330 & $7.9 \%$ & $66.0 \%$ \\
\hline Arms smuggling & 230 & $5.5 \%$ & $46.0 \%$ \\
\hline Total & 4170 & 100.0 & $834.0 \%$ \\
\hline
\end{tabular}

Source: Fieldwork, 2016

Poverty and limited employment opportunities are seen as the main developmental problems of the community. Many border residents see legitimate opportunities for livelihood as limited within their community. They are therefore likely to see activities such as smuggling as appropriate means to cope with the challenge of limited employment opportunities.

The respondents were asked if they think some members of their community engage in cross border crimes. Table 6 shows that 73.2 percent of the respondents thought that, segments of the community were engaged in cross-border crimes. Only 26.8 percent of them denied knowledge of the involvement of residents in cross border crimes. This indicates an active participation of residents in cross border crimes. The respondents were also asked which cross border crimes involve members of their community. The responses to this question show that armed robbery and petty stealing was the main cross-border crime committed by the community members. The majority $(30.4 \%)$ of the respondents who thought that their community members were engaged in cross-border crimes stated that armed robbery and stealing were the 
main cross-border crimes involving the residents. An equally large percentage of 15.6 percent of the respondents held that drug trafficking was the main crime involving residents. Issues of arms trafficking (8.0\%), goods smuggling (4.6\%) and human trafficking (14.6) were the other forms of crimes involving their community residents (See table 6).

Table 6: Involvement of residents in cross border crimes

\begin{tabular}{|c|c|c|c|}
\hline & & Frequency & Percent \\
\hline \multirow{3}{*}{$\begin{array}{l}\quad \text { A. Do you } \\
\text { think some } \\
\text { members of your } \\
\text { community engage } \\
\text { in cross border } \\
\text { crime? }\end{array}$} & Yes & 366 & 73.2 \\
\hline & No & 134 & 26.8 \\
\hline & Total & 500 & 100.0 \\
\hline \multirow{7}{*}{\begin{tabular}{l}
\multicolumn{1}{c}{ B. Which } \\
crimes do they \\
normally \\
participate in?
\end{tabular}} & Drug trafficking & 78 & 15.6 \\
\hline & $\begin{array}{c}\text { Armed } \\
\text { robbery/Petty S. }\end{array}$ & 152 & 30.4 \\
\hline & $\begin{array}{l}\text { Human } \\
\text { trafficking }\end{array}$ & 73 & 14.6 \\
\hline & Arms trafficking & 40 & 8.0 \\
\hline & $\begin{array}{c}\text { Goods } \\
\text { Smuggling }\end{array}$ & 23 & 4.6 \\
\hline & N/A & 134 & 26.3 \\
\hline & Total & 500 & 100.0 \\
\hline
\end{tabular}

Source: Fieldwork, 2016

It is instructive that regardless of evidence that good smuggling is common among border residents (Nugent, 2011; Nugent, 1991; Kumar, 1973; Nugent, 2002; Raunet, 2016) in Ghana, only 4.6 percent of the respondents mentioned goods smuggling as a crime involving members of the community.

The respondents were asked if they "are aware of people in your community who help 'strangers' or smugglers carry goods across the border to avoid the border agencies at a fee?" In response, 92.7 percent of them stated that they were aware of people who aid strangers carry goods across the border for a fee in the community. Only 7.3 percent of the respondents mentioned that they were not aware. Juxtaposing this with the earlier data regarding respondents who thought that their community members engage in cross-border crimes (see table 6), it is evident that many of the respondents do not regard helping travellers/strangers to cross the border with goods in return for money as a crime. Indeed, 19.5 percent more of the respondents agreed to be aware of people within their community helping travellers to avoid the border agencies than those who agreed that their community members were engaged in cross-border crimes.

It is also important to note that, although, 92.7 agreed that people in the community aid travellers to cross the border, only 4.6 percent mentioned goods smuggling as a crime involving residents. Here, 88.1 percent more of the respondents agreed that residents assist travellers/smugglers in comparison to those who mentioned that the residents were involved in smuggling. This poses the question of why the large number of respondents agreed that residents assist smugglers but only few mentioned smuggling as a crime involving the residents. A possible explanation lies in the subculture of borderlands, which legitimizes smuggling. Thus, respondents' responses might have been conditioned by a subculture that accepts goods smuggling as a legitimate business. As will be demonstrated in subsequent sections, many of the residents accept smuggling as contributing to reducing unemployment in the community.

Similarly, respondents were asked if there are people in the community who assist 'strangers'/smugglers to pass routes that border agencies cannot dictate for a fee? To this question, 84.2 percent of the respondents agreed to be aware of people in the community who assist 'strangers' to pass routes that border agencies cannot dictate for a fee. Just 15.8 percent stated that they were not aware (table 7).

Table 7: Involvement of residents in facilitating Smuggling

\begin{tabular}{|c|c|c|c|}
\hline \multicolumn{2}{|c|}{ Prequency } & Percent \\
\hline A. Are you aware of people in & Yes & 463 & 92.6 \\
\hline
\end{tabular}




\begin{tabular}{|c|c|c|c|}
\hline \multirow{2}{*}{$\begin{array}{l}\text { your community who help } \\
\text { 'strangers'/smugglers carry goods across } \\
\text { the border to avoid the border agencies at a } \\
\text { fee? }\end{array}$} & No & 37 & 7.4 \\
\hline & Total & 500 & 100.0 \\
\hline \multirow{3}{*}{$\begin{array}{l}\text { B. Are there people in your } \\
\text { community who assist } \\
\text { 'strangers'/smugglers to pass routes that } \\
\text { border agencies cannot dictate for a fee? }\end{array}$} & Yes & 421 & 84.2 \\
\hline & No & 79 & 15.8 \\
\hline & Total & $\mathbf{5 0 0}$ & 100.0 \\
\hline
\end{tabular}

Source: Fieldwork, 2016

Again, in comparison to the earlier data on awareness about residents being engaged in cross border crimes, it is obvious that many more respondents agreed to be aware of the residents assisting strangers to pass routes in order to avoid border agencies than those who thought the residents engage in cross border crimes. Here, 11 percent more of the respondents were aware of residents assisting people through routes in the community to avoid border security system than those who stated that the residents were engaged in cross border crimes. It appears from this response that to the respondents some forms of cross border crimes such as goods smuggling, aiding smugglers and other people who want to evade border security systems appears a 'legitimate' business.

In response to the question of "if respondents have assisted any one to cross the border without the knowled ge of the security agencies", some 41.6 percent of them agreed to have assisted a stranger to cross the border without knowledge of the security agencies. This implies that for every ten (10) residents of area, an estimated four (4) of them had assisted a stranger to cross the border without the knowledge of the security agencies. In other words, an estimated four in every ten residents of the area have helped in outwitting Ghana's border security setup, thereby aiding one crime or another.

Among those who ever assisted someone to cross the border, 64.4 percent of them assisted people who carried items or goods across the border. Out of this number, only 39.6 percent were able to identify the content of what the stranger(s) they assisted was carrying. For the larger 60.4 percent of the respondents who assisted people carrying items, they could not identify the items the people were carrying. This means that many of the residents may be aiding crimes such as drug trafficking and arm trafficking unintentionally.

The reasons for engagement in this action vary among the respondents. Of all those who have ever assisted someone cross the border, 23.1 percent did it in return for money or some other reward and, for the majority of some 49.0 percent of them, it is the source of their livelihood. Thus, money influenced 69.1 percent of those who ever assisted people crossed the border without the knowledge of the security agencies. Some $(15.4 \%)$ respondents assisted people to cross the border on compassionate grounds to help 'stranded' travellers. Additional 12.5 percent cannot tell their reason for assisting people cross the border. (See table 8).

Table 8 Respondents involvement in cross border crimes

\begin{tabular}{|c|c|c|c|}
\hline \multicolumn{2}{|c|}{} & $\begin{array}{l}\text { Frequenc } \\
\text { y }\end{array}$ & Percent \\
\hline \multirow{2}{*}{$\begin{array}{c}\text { A. Have you ever assisted a } \\
\text { stranger(s) to cross the without the } \\
\text { of the security agencies? }\end{array}$} & Yes & 208 & 41.6 \\
\cline { 2 - 4 } & No & 292 & 58.4 \\
\cline { 2 - 4 } & Total & $\mathbf{5 0 0}$ & $\mathbf{1 0 0 . 0}$ \\
\hline $\begin{array}{c}\text { B. If 'Yes' in A, was the } \\
\text { stranger you assisted with any } \\
\text { goods or items }\end{array}$ & Yes & 134 & 64.4 \\
\cline { 2 - 4 } & No & 74 & 35.6 \\
\cline { 2 - 4 } & Total & $\mathbf{2 0 8}$ & $\mathbf{1 0 0 . 0}$ \\
\hline \multirow{2}{*}{$\begin{array}{c}\text { C. If 'Yes' in B, were you } \\
\text { able to identify the content of what } \\
\text { the stranger was travelling with? }\end{array}$} & Yes & 53 & 39.6 \\
\cline { 2 - 4 } & No & $\mathbf{1 3 4}$ & $\mathbf{1 0 0 . 0}$ \\
\cline { 2 - 4 } & Total & & \\
\hline
\end{tabular}




\begin{tabular}{|l|l|r|c|}
\hline \multirow{2}{*}{$\begin{array}{c}\text { D. If 'Yes' in A, why did you } \\
\text { assist him/her to cross the border? }\end{array}$} & In return for money & 48 & 23.1 \\
\cline { 2 - 4 } & To help a stranded person(s) & 32 & 15.4 \\
\cline { 2 - 4 } & $\begin{array}{c}\text { That is the work I do for a } \\
\text { living }\end{array}$ & 102 & 49.0 \\
\cline { 2 - 4 } & I can't tell & 26 & 12.5 \\
\cline { 2 - 4 } & Total & $\mathbf{2 0 8}$ & $\mathbf{1 0 0 . 0}$ \\
\hline
\end{tabular}

Source: Fieldwork, 2016

Here, it is clear that many residents see aiding of people to cross the border as an avenue to make money. As shown above, aiding people to cross the border is the means of earning livelihood by many of the respondents who agreed to ever assist people cross the border. This is an indication that this activity is quite widespread in area.

When the respondents were asked if involvement of residents in assisting people with goods across the border or helping them pass through routes the security cannot dictate is helping to reduce unemployment and other crimes, many of them responded in the affirmative. A large number of 83.6 percent of the respondents stated that carrying goods or helping people cross the border at the blind side of the security agencies is helping reduce unemployment and the engagement of youths in other crimes. Fewer numbers $(9$ percent) of them thought otherwise and, 7.4 percent were not sure. This supports the findings of many scholars on borderland communities that within borderlands smuggling and smuggling facilitation are often seen as sources of legitimate livelihood (Nugent, 2011; Flynn, 1997; Galemba, 2012; MacGaffey, 1991; Nugent, 2002). Smuggling and smuggling facilitation are coping strategies for the limited employment opportunities within the borderland.

\section{Conclusion}

In borderlands, cross border mobility and exchange are important for livelihoods. The border economy is largely an informal economy based mainly on cross border trade, both legitimate and illegitimate. Faced with the challenge of poverty and unemployment, among other problems, borderlanders historically have exploited their embeddedness in the border space as coping strategy by engaging in officially proscribed activities, mainly smuggling and smuggling facilitation. For many border residents, aiding smuggling or goods smuggling offers them an opportunity to overcome the challenges of unemployment and poverty, and therefore represent legitimate avenues for reducing unemployment. Many border residents depend on these activities as their livelihood.

Apart from goods smuggling and facilitating smuggling, border residents are also involved in crimes such as armed robbery and petty stealing, drug trafficking, human trafficking and arms trafficking. However, while many border residents are likely to see these other activities (armed robbery and petty stealing, drug trafficking, human trafficking and arms trafficking) as crime, they would normally accept that smuggling and aiding smuggling are not crimes. However, through aiding of people to cross the border, many of the residents unintentionally contribute to these other crimes, particularly arm trafficking and drug trafficking, since most of them may not be aware of the content of the items they are contracted to carry across the border. Besides, both goods smuggling and smuggling facilitation remain officially crimes in modern Ghanaian law, hence, legitimatization within the subculture of borderlands does not make them legal.

In fine, this survey evidence from Aflao has confirmed existing evidence (Nugent, 2011; Flynn, 1997; Nugent, 2002) that involvement in cross border crimes is common among borderlanders as a coping strategy to unemployment. These findings have important implications for efforts at addressing cross border crimes in Ghana. Unemployment and poverty have made border residents vulnerable to recruitment by transnational and individual criminals as couriers. Thus, border security efforts need to be comprehensive to encapsulate the livelihood demands of borderlanders. Just as the state is present in the border areas to extract revenue through import duties, it should be ready to provide livelihood options for border residents. It is obvious that unless border management is seen as a comprehensive effort, which involves addressing socio-economic 
needs of border residents, border management efforts would be undermined by the activities of border residents.

There is also the need to reorient border residents to understand the security implications of their activities and solicit their integration into border security policy space. Borderlanders should be seen as important actors in the border space with interests in the operations of the border. The adoption of the integrated border management approach, which allow for collaboration and cooperation among all stakeholders in the border space is an important first step to addressing this challenge.

\section{References}

[1] Addo, P. (2006). Cross-Border Criminal Activities in West Africa: Options for Effective Responses. KAIPTC Paper(12).

[2] Adeyemi, A. E. (2015). Terrorism and Transnational Security Threat in West Africa: The Global Perspective. Xlibris Corporation.

[3] Agade, K. M. (2014). Ungoverned Space' and the Oil Find in Turkana, Kenya. The Round Table: The CommonWealth Jounal of International Affairs, 105(5), 497-515 .

[4] Agbedahin, K. (2014). From control to parasitism. African Security Review, 23(4), 370-380.

[5] Agnew, R. (2000). Source of criminality: strain and subcultural theories. In J. Sheley, Criminology: A Contemporary Handbook (pp. 349-371). Belmont, CA: Wadsworth.

[6] Agnew, R. (2016). Strain, Economic Status, and Crime. In A. R. Piquero, The Handbook of Criminological Theory (pp. 209-229). Wiley Blackwall.

[7] Akyeampong, E. (2005). "Diaspora and Drug Trafficking in West Africa-A case study of Ghana. African Affair(416), 432-434.

[8] Aning, K. (2007). Are there Emerging West African Criminal Networks? The Case of Ghana. Global Crime, 8(3), 193-212.

[9] Azure Junior, F. (1999). The Customs Excise And Preventive Service And Cross Border Crimes Management: A Case Study Of The Eastern Frontier Of Ghana. Retrieved June 25, 2016,fromhttp://ir.knust.edu.gh/bitstream/123456789/618/1/Francis\%20Azure\%20Junior.pdf

[10] Bailey, K. D. (1994). Methods of Social Research (4 ed.). New York;Toronto: Free Press.

[11] Baron, S. (2014). Monetary strain and individual offending. In G. Bruinsma, \& D. Weisburd, Encyclopedia of Criminology and Criminal Justice (pp. 3127-3137). New York: Springer.

[12] Blum, C. (2014). Cross-Border Flows between Nigeria and Benin: What are the Challenges for (Human) security? Abuja:: Friedrich-Ebert-Stiftung.

[13] Buliř, A. (1998). The Price Incentive to Smuggle and the Cocoa Supply in Ghana. IMF Working Paper(WP98/88).

[14] Burton, V. J., \& Dunaway, R. (1994). Strain, relative deprivation, and middle $\square$ classdelinquency. In G. Barak, Varieties of Criminology (pp. 79-95). Westport, CT: Praeger.

[15] Chalfin, B. (2001). Border Zone Trade and the Economic Boundaries of the State in North-East Ghana. Africa: Journal of the International African Institute, 71(2), 202-224.

[16] Cloward, R., \& Ohlin, L. (1960). Delinquency and Opportunity. New York: Free Press.

[17] Clunan, A. L., \& Trinkunas, H. A. (2010). Ungoverned Spaces: Alternative to State Authority in an Era Softened Sovereignty. (A. LClunan, \& H. A. Trinkunas, Eds.) Standford: Stand ford University Press.

[18] Cockayne, J. (2011, December). Transnational Threat: The Criminalization of West Africa and the Sahel. Policy Brief, Center on Global Counter Terrorism Cooperation,.

[19] Cohen, A. 1. (1955). Delinquent Boys. New York: Free Press.

[20] Collins, D. (1985). "Partitioned Culture Areas and Smuggling: The Hausa and Groundnut Trade across the Nigeria- Niger Boundary up to the 1970s. In A. I. Asiwaju, Partitioned Africans (pp. 195 221.). london: C.Hurst.

[21] Collins, D. (1985). Partitioned Culture Areas and Smuggling: The Hausa and Groundnut Trade across the Nigeria-Niger Boundary up to the 1970s. In Partitioned Africans. In A. I. Asiwaju, \& A. A. I. (Ed.), Partitioned Africans (pp. 195-221). London: C. Hurst.

[22] Flynn, D. K. (1997). "We Are the Border": Identity, Exchange, and the State along the Benin -Nigeria Border. " American Ethnologist, 24(2), 311-330.

[23] Foreman, E. (1991). Survey Sampling Principles. New York: Marcel Dekker, Inc. 
[24] Galemba, R. B. (2012). Taking Contraband Seriously: Practicing "Legitimate Work" at the MexicoGuatemala Border. Anthropology of Work Review, 33(1), 3-14.

[25] Ismail, O. (2013). The Regionalanand International Dimension of Radicalisation and Violence Extremism in West Africa. In J. Gow, F. Olonisakin, \& E. Dijxhoorn, Militancy and Violence in West Africa: Religion, Politics and radicalisation (pp. 235-255). New York: Routledge.

[26] Jang, S. J., \& Agnew, R. (2015). Strain Theories and Crime. In J. D. Wright, International Encyclopedia of the Social \& Behavioral Sciences (2 ed., Vol. 23, pp. 495-500). Oxford: Elsevie.

[27] Konrad, V. (2014). Borders and Culture: Zone of Transition, Interaction and identity in the CanadaUnited State Borderlands. Eurasia Review, 5(1).

[28] Kristof, L. K. (1959). Nature of Frontiers and Boundaries. Annals of the Association of American Geographers, 49(3), 269-282.

[29] Kumar, A. (1973). Smuggling in Ghana: Its Magnitude and Economic Effects. The Nigerian Journal of Economic and Social Studies,, 15(2), 285-303.

[30] Lamptey, A. A. (2013). Rethinking Border security in West Africa: Experience from the Sahel. KAIPTC Policy Brief.

[31] Lentz, C. (2003). This is Ghanaian Territory": Land Conflicts on a West Africa Border. American Ethnologist, 30(2), 273-289.

[32] MacGaffey, J. (1991). The Real Economy of Zaire: The Contribution of Smuggling and Other Unofficial Activities to National Wealth. London: James Currey.

[33] Martínez, O. J. (1994). Border People: Life and Society in the U.S.-Mexico Borderlands. Tucson: University of Arizona Press.

[34] Mazzitelli, A. L. (2007 ). Transnational organized crime in West Africa: the additional challenge. International Affairs, 83(6), 1071-1090.

[35] McGregor, J. (2008). 'Patrolling Kariba's Waters: State Authority, Fishing and the Border Economy. Journal of Southern African Studies, 34(4), 861-871.

[36] Merton, R. K. (1983). Social Structure and Anomie. American Sociological Review, 3(5), 672-682.

[37] Nugent, P. (1991). Educating Rawlings: The Evolution of Government Strategy towards Smuggling. In D. Rothchild, Ghana: the Political Economy of Recovery (pp. 69-84). Boulder CO: Lynne Rienner Publishers.

[38] Nugent, P. (2002). Smugglers, Secessionists, and Loyal Citizens on the Ghana-Togo Frontier. AthensOH: Ohio University Press.

[39] Nugent, P. (2011). Bourdieu and De Certeau at the Border Post: Trans-boundary Communities, Government Officials and Everyday Life in West Africa. In E. S.-Y. Nikolaus Schareika, Auf dem Boden der Tatsachen: Festschriftfur Thomas Bierschenk (pp. 361-376). Koln: Rudiger Koeppe Verlag.

[40] Nugent, P., \& Asiawuja, I. (1996). African boundaries : barriers, conduits and opportunities. London; New York: Pinter.

[41] Oxford Business Group. (2013). The Report: Ghana 2013. Accra: : Oxford Business Group.

[42] Parker, K. (2008). Unequal Crime Decline. New York: New York University Press.

[43] Quaye, R., \& Coombs, H. (2011). "The Implementation of Anti-Money Laundering, Terrorist Finance and Corruption Laws in Ghana. International Journal of Governmental Financial Management, 11(2), 50 - 59.

[44] Raunet, N. (2016). Chiefs, Migrants and the State: Mobility in the Ghana-Togo Borderlands. COMPAS Working Paper(131).

[45] Schendel, W. v., \& Abraham, I. (2005). Illicit Flows and Criminal Things: States, Borders, and the Other Side of Globalization. (W. v. Schendel, \& I. Abraham, Eds.) Indianapolis: University of Indiana Press.

[46] Sosuh, M. M. (2011). "Border Security in Ghana: Challenges and Prospects,. KAIPTC Occasional Paper(32).

[47] US Department of State. ( 2016). Trafficking in Persons Report. US State Department. Retrieved October 15, 2015, from Ghana: 2013 Trafficking in Persons Report: http://www.state.gov/j/tip/rls/tiprpt/countries/2013/215470.htm

[48] US State Department. (2014). International Narcotics Control Strategy Report. US Department of State 